\title{
Molecular and pathological studies of duck hepatitis virus in Egypt
}

\author{
Ali Zanaty ${ }^{*}$, Naglaa Hagag, Mohamed Samy, Ahmed abdel-Halim, Mohamed \\ A. Soliman, Abdel-Satar Arafa, Soad Nasif
}

National Laboratory for Veterinary Quality Control on poultry production NLQP, P.O. Box 264, Dokki, 12618, Giza, Egypt.

\begin{tabular}{|c|c|}
\hline Abstract & ARTICLE INFO \\
\hline $\begin{array}{l}\text { Duck Hepatitis virus (DHV) causes great economic losses in waterfowl } \\
\text { industry worldwide. } 3 \mathrm{D} \text { gene, lies in the P3 segment of the picornavirus } \\
\text { genome, is highly conserved and is a non-structural polyprotein gene, its } \\
\text { encoding protein contains a conserved domain termed RNA-dependent- } \\
\text { RNA polymerase which participates in the synthesis of virus RNA } \\
\text { during virus replication. The current work describes the surveillance of } \\
\text { DHV in } 20 \text { commercial duck farms in Egypt with a history of high } \\
\text { mortality in } 3 \text { to } 15 \text { day-old young ducklings from } 2014 \text { to } 2016 \text {. Clinical } \\
\text { samples were examined by Real Time-Polymerase Chain Reaction } \\
\text { assays followed by partial sequence analysis of the 3D gene of the } \\
\text { positive samples. Histopathological examination of the liver from } \\
\text { selected samples was also conducted. The overall positive rate was } 50 \% \\
\text { (n = 10/20). All duck breeds (Pekin, Muscovy and Mallard) used in the } \\
\text { study were found to be susceptible to the disease. Histopathological } \\
\text { findings of the liver samples showed pronounced lesions including } \\
\text { hepatocyte degeneration and necrosis. Also, apoptosis were observed and } \\
\text { bile duct hyperplasia, together with varying degrees of inflammatory cell } \\
\text { response and haemorrhage. Sequence and phylogenetic analyses } \\
\text { indicated that the Egyptian strains cluster in the DHAV serotype } 1 \text { with } \\
\text { Asian viruses and distant from the vaccine strains used in Egypt. }\end{array}$ & $\begin{array}{l}\text { Keywords: } \\
\text { Duck Hepatitis virus } \\
\text { (DHV), } \\
\text { Histopathology, 3D } \\
\text { gene, Sequencing, } \\
\text { Phylogeny. }\end{array}$ \\
\hline
\end{tabular}

Corresponding author: Ali Zanaty e-mail: zanatyali@yahoo.com

\section{Introduction}

Duck hepatitis virus (DHV) is an acute highly contagious fatal and rapidly spreading viral infection of young ducklings. It is one of the most common diseases affecting growing duck flocks and causes severe economic losses because of its high mortality. Duck hepatitis 
virus (DHV) was primarily recoded in New York and in 1949 (Levine and Fabricant, 1950). The morbidity is $100 \%$ and the mortality may reach $95-100 \%$, in the first week of age (Mahdy, 2005). Survived ducklings infected with DHV have a solid immunity, but it is important to secure the duck industry against such lethal disease using the strong-specific vaccine. Live attenuated DVH-1 vaccine administrated via the intramuscular route in breeder ducks 2-3 weeks before lying lead to the transfer of high maternal derived antibody to the offspring providing them with passive immunity that is able to protect the new hatched birds up to 15 days of age (Saif, 2003).

DHV-1 is renamed duck hepatitis A virus (DHAV) and is assigned to the unique genus Avihepatovirus within the family Picornaviridae (Knowles et al., 2012). DHAV is branched genetically into 3 different genotypes found in south Asia: the original genotype DHAV-1, a new genotype DHAV-2 isolated in Taiwan and a new genotype DHAV-3 isolated in South Korea and China (Kim et al., 2007; Fu et al., 2008). DHV-1 is a non-enveloped small virus with a positivepolarity, single-stranded RNA genome of approximately $7.8 \mathrm{~kb}$ (KIM et al., 2006; Ding and Zhang, 2007; Liu et al., 2007; Tseng et al., 2007).

The genomic organization of viruses in Picornaviridae owns a similar structure as follows 5'UTR-L-VP4-VP2-VP3-VP1-2A2B-2C-3A-3B-3C-3D-3'UTR. 3D gene is a non-structural polyprotein gene, its encoding protein contains a conserved domain termed RNA-dependent-RNA polymerase (RdRp, also named 3D polymerase or 3Dpol) which participates in the synthesis of virus RNA during virus replication (Kim et al., 2006). RdRp is the most important part of the virus RNA synthase, and it has been confirmed to possess enzyme activity through the synthesis of negative strand RNA (Kerkvliet et al., 2010).
Experimentally, DHAV can be transmitted by parental and/or oral routes, but vertical transmission has not been yet recorded. DHAV causes infection in Mallard and Pekin ducklings but now, it is identified to cause pancreatitis and encephalitis in Muscovy ducks (Guerin et al., 2007). The diagnosis of DHAV usually depends on epidemiological data, clinical symptoms, pathological lesions and viral isolation. Traditional detection techniques include direct fluorescenceantibody test on livers obtained from field cases or on duck embryos inoculated with DHAV (Miaboroda, 1972; Vertinskii et al., 1986) and the procedures for detection of antibody against DHAV in duck sera include neutralization tests (Hwang, 1969; Woolcock et al., 1982), indirect hemagglutination tests (Taylor and Hanson, 1967), gel diffusion assays (Gabridge and Newman, 1971) and ELISA (Zhao et al., 1991). These assays are time-consuming and don't give the required sensitivity to detect low-level of virus (Ling et al., 2007).

In 1970, the virus spread in Egypt (Shalaby et al., 1972). Recently, epidemiology and molecular characterization of DHAV from different duck breeds in Egypt was studied by Erfan et al. (2015) and Bayoumie and Abd EL-Samie (2015). Duck farms in Egypt are usually protected against DHV following a vaccination program targeting DHV-1 using attenuated vaccines produced from E52 Rispens strain for breeder ducks (Ellakany et al., 2002; Abd-Elhakim et al., 2009). Unluckily, some duck farms stopped vaccination against DHV causing the reappearance of disease outbreaks (Mahdy, 2005).

In this study, we report and analyse the partial nucleotide sequence of the 3D gene for ten DHV-1 strains. Genetic and phylogenetic analyses for the 3D gene were done. The histopathological picture for the liver of infected ducks was studied. 


\section{Materials and Methods}

\subsection{Samples}

Liver, spleen and kidneys samples from freshly dead or euthanized birds were collected from different breeds of ducks (Pekin, Muscovy and Mallard) in 20 commercial flocks in Egypt from 9 different governorates (Table 1) with a history of nervous signs and high mortality rate during the first 3 weeks of life. Samples were obtained from the. Organs were homogenised using the Tissuelyser I (Qiagen) then conducted to three successive freeze-thaw cycles, and the supernatant fluid was separated after $12,000 \mathrm{rpm}$ centrifugation for $10 \mathrm{~min}$. and kept in -80C.

\subsection{Histopathology}

Livers samples collected from freshly dead ducklings and fixed in 10\% natural formalin and processed by routine histopathological techniques. Sections of $4 \mu \mathrm{m}$ in thickness were cut and mounted on microscope slides that were stained with haematoxylin and eosin (Bancroft and Gamble, 2008).

\subsection{Virus detection}

RNA extraction from the supernatants of tissue homogenates was performed using the QIAamp Viral RNA Minikit (Qiagen, Germany, $\mathrm{GmbH}$ ) according to the manufacturer's instructions. The One step reverse transcriptase polymerase chain reaction assays using oligonucleotide for partial amplification of $467 \mathrm{bp}$ of the 3D gene was conducted using DHV-1 ComF (5'-AAGAAG-GAG-AAA-ATY-- AAG-GAA-GG-3') DHV-1 ComR (5'-TTG-ATG-TCA-TAG CCC-AAS- -ACA-GC-3') (OIE, 2010).

A twenty five-ml reaction containing 12.5 $\mathrm{mL}$ of Qiagen one step RT-PCR buffer (Qiagen, Germany, GmbH), $0.25 \mathrm{~mL}$ of RTenzyme, $1 \mathrm{~mL}$ of each primer of $20 \mathrm{pmol}$ concentration, $4.25 \mathrm{~mL}$ of water and $6 \mathrm{~mL}$ of template RNA was used. The reactions were performed in a T3 thermal cycler (Biometra). The amplicons were electrophoresed on $1.5 \%$ agarose gel (Applichem, Germany, GmbH) along with 100- bp DNA Ladder (Qiagen, Germany, GmbH). The data were analysed by Automatic Image Capture Software (Biosciences, USA).

\subsection{Virus isolation}

The homogenized sample suspension was clarified by centrifugation for $10 \mathrm{~min}$ at 3000 rpm (OIE, 2010). The processed sample was inoculated into allantoic sac of 8-10 day-old SPF embryonated chicken eggs (); $0.2 \mathrm{ml}$ /embryo using standard techniques of embryo inoculation. Each of the inoculated embryos was monitored for embryopath daily for 5-8 days.

\subsection{Sequence and phylogenetic analyses}

Partial sequences of the 3D gene of the 10 field viruses were generated using forward and reverse primers of the generic PCRs. Amino acid sequences were deduced from the generated nucleotides using BioEdit software version 7.1.7 (Hall, 1999). Sequences of query and representative DHAVs were retrieved from the GenBank database. All sequences were aligned and identity matrices were calculated automatically using BioEdit. Phylogenetic analyses were done using neighbour joining method of MEGA6 softwere (Tamura et al., 2013). Consensus unrooted phylogeny were generated with 1000 bootstrap replicates.

\section{Results}

\subsection{Virus screening and isolation}

Out of the 20 samples tested by RT-PCR, 10 samples were tested positive (50\%). PCR product ampliconof 460-bp of the 3D gene of DHV was obtained from the positive samples. Virus isolation was obtained from the homogenate pool of the liver samples 
from each flock. The 10 samples were also positive in virus isolation in EDE (stunting, subcutaneous haemorrhages of the embryos, haemorrhagic enlarged liver, enlarged mottled spleen and enlarged kidneys).
Affected ducklings characterised by lethargy and ataxia followed by paddling spasmodically. Gross pathological changes were shown mainly in the liver, which was swollen and displayed distinct petechial and ecchymotic haemorrhages. Spleen and kidneys may show enlargement and swelling

\subsection{Clinical and necropsy findings}

Table 1. Positive samples collected from commercial duck farms in Egypt in this stud

\begin{tabular}{|c|c|c|c|c|c|}
\hline No. & Code & Governorates & Breed & $\begin{array}{c}\text { Collection } \\
\text { date }\end{array}$ & $\begin{array}{l}\text { Accession } \\
\text { number }\end{array}$ \\
\hline 1 & DHV-EGYPT/14921F-2014 & Qaluibia & Pekin & 2014 & KX639139 \\
\hline 2 & DHV-EGYPT/14923F-2014 & Giza & Muscovy & 2014 & KX639140 \\
\hline 3 & DHV-EGYPT/141122F-2014 & Behara & Pekin & 2014 & KX639141 \\
\hline 4 & DHV-EGYPT/151283F(3)-2015 & Sharkia & Pekin & 2015 & KX639142 \\
\hline 5 & DHV-EGYPT/15298F-2015- & Fayoum & Mallard & 2015 & KX639143 \\
\hline 6 & DHV-EGYPT/15P18-2015 & Menoufiya & Muscovy & 2015 & KX639144 \\
\hline 7 & DHV-EGYPT/151283F(4)-2015 & Beni-Suef & Mallard & 2015 & KX639145 \\
\hline 8 & DHV-EGYPT/16160F-2016 & Sharkia & Muscovy & 2016 & KX639146 \\
\hline 9 & DHV-EGYPT/151283F(2)-2015 & Gharbia & Muscovy & 2015 & KX639147 \\
\hline 10 & DHV-EGYPT/151283F(1)-2015 & Ismailia & Muscovy & 2015 & KX639148 \\
\hline
\end{tabular}

\subsection{Histopathology}

Microscopic changes in the liver were characterised by vacuolar degeneration and extensive hepatocyte necrosis. Also, apoptosis were observed and bile duct hyperplasia, together with varying degrees of inflammatory cell response and haemorrhage. Nuclei of hepatocytes showed pyknosis and karyorrhexis.

\subsection{Phylogenetic analysis}

The Egyptian strains have amino acid identity ranged from 91 to $92 \%$ and nucleotide identity from 78 to $80 \%$ with the vaccine strain used in Egypt (Table 2). The phylogenetic relationship using the partial 3D protein revealed that the isolated Egyptian strains in this study were distant from the vaccine strain used in Egypt and closely related to the Asian strains (Figure $1)$.

In comparison to the vaccine strain, the Egyptian viruses possess H10Y, D20E, F22Y, I32L, C44A, T70A and Y82F (except strain no.6), A95E, R92K and V125L (except strain no.6 (V125I)). Strain no.8 (DHVEgypt/16160F-2016) isolated in 2016 showed more amino acids changes in relation to other strains isolated during this study and less amino acid change in comparison to the vaccine strain at position 95 and 110 . 


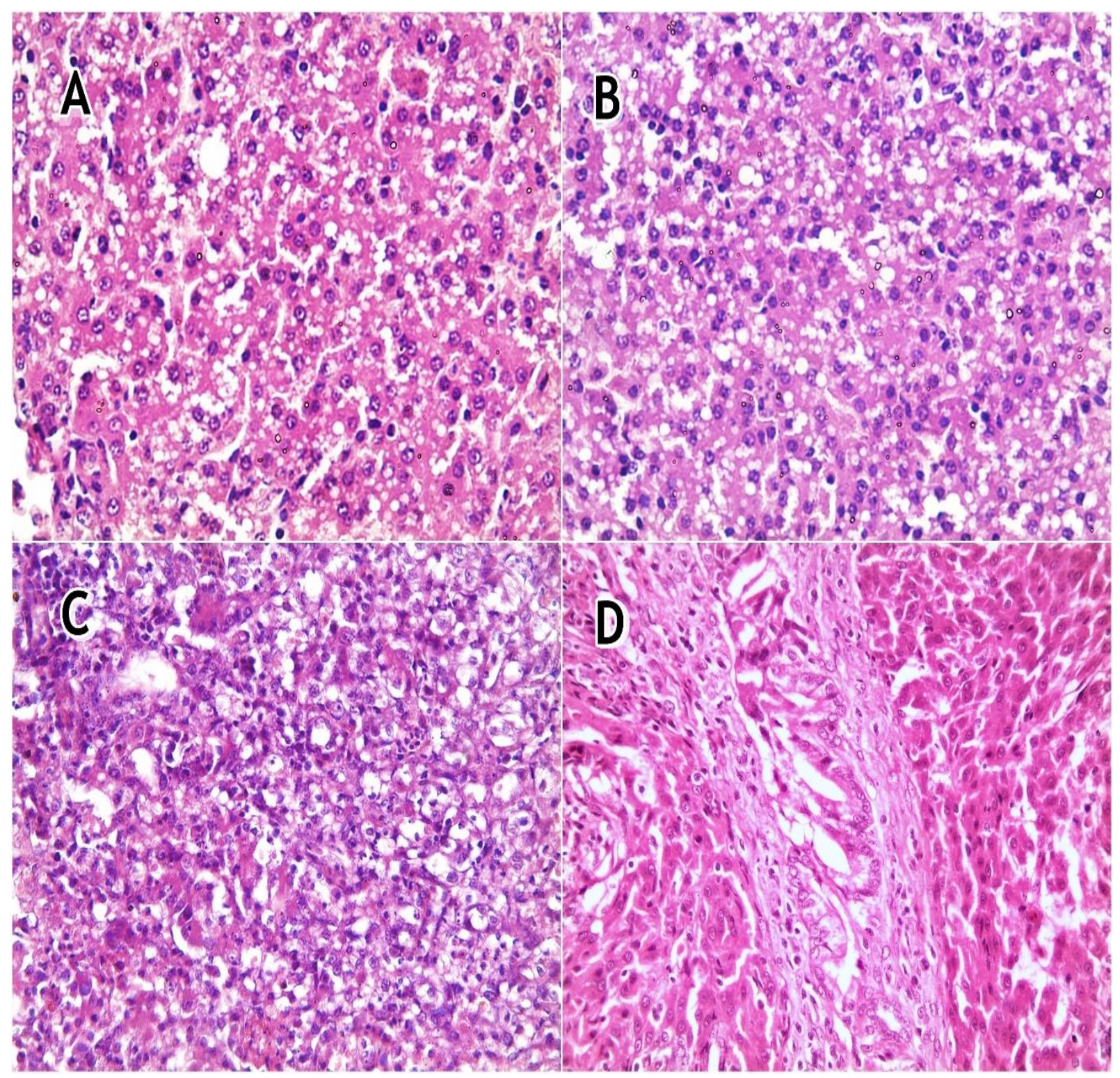

Figure 1 (A, B). Liver of affected ducklings showed diffuse vacuolar degeneration H\&E x200. (C) Liver showed severe necrosis of hepatocytes associated with apoptotic bodies H\&E x200. (D) Bile duct of hyperplasia of epithelial lining result in severe narrowing of bile duct lumen H\&E x 200 . 


\section{Ali Zanaty et al (2017)}

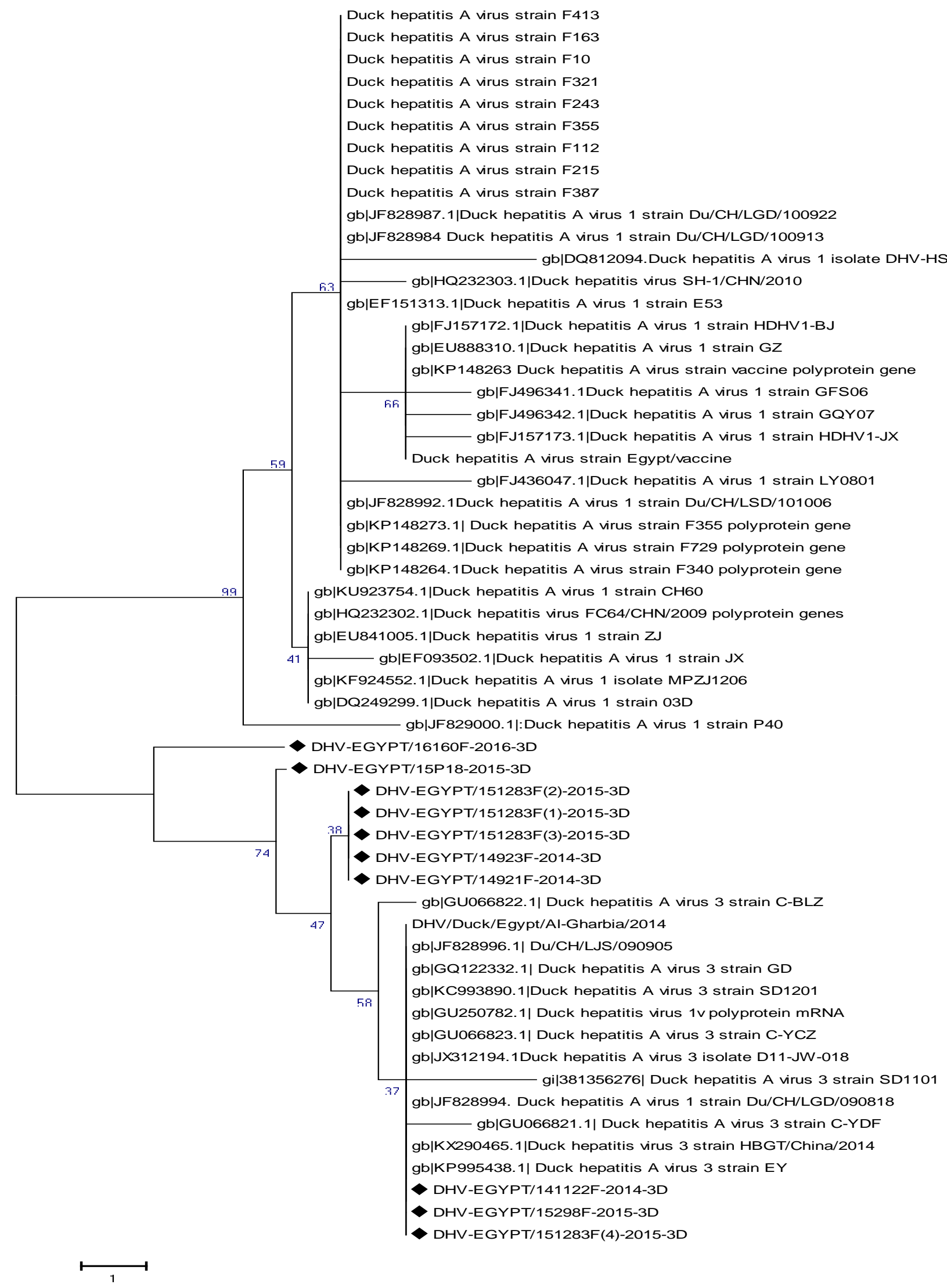

Figure 2. Amino acids neighbour-joining phylogenetic tree for the $5 \mathrm{DHV}$ isolates (marked with black diamond) and related DHV vaccinal and reference strains based on the partial 3D gene sequence. 
Table 2. Nucleotide and amino acid identities of Egyptian isolates with selected references and vaccinal DHV sequences of different serotypes.

Strain name

Nucleotide identity \% (upper right)

Amino acid identity \% (lower left)

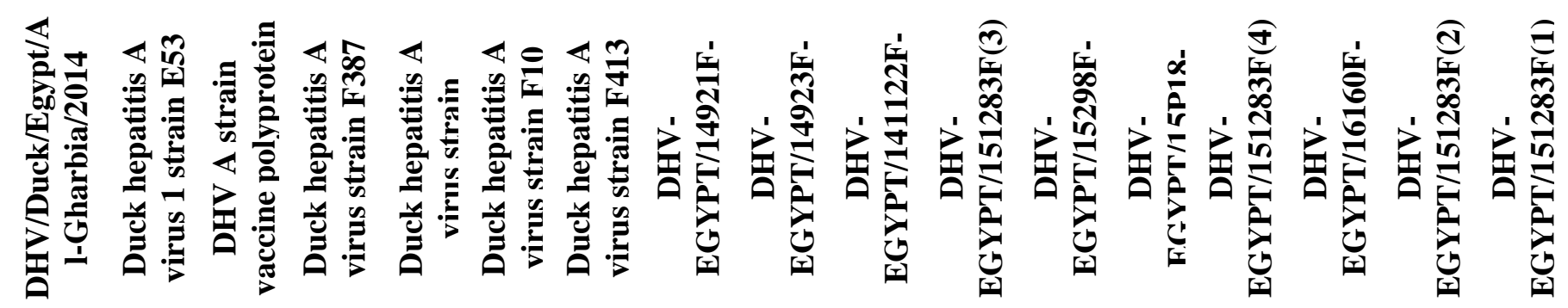

DHV/Duck/Egypt/Al-Gharbia/2014

Duck hepatitis A virus 1 strain E53

DHV A strain vaccine polyprotein gene

Duck hepatitis A virus strain F387

Duck hepatitis A virus strain

Egypt/vaccine

Duck hepatitis A virus strain F10

Duck hepatitis A virus strain F413

DHV-EGYPT/14921F-2014-3D

DHV-EGYPT/14923F-2014-3D

DHV-EGYPT/141122F-2014-3D

DHV-EGYPT/151283F(3)-2015-3D

DHV-EGYPT/15298F-2015-3D

DHV-EGYPT/15P18-2015-3D

DHV-EGYPT/151283F(4)-2015-3D

DHV-EGYPT/16160F-2016-3D

DHV-EGYPT/151283F(2)-2015-3D

DHV-EGYPT/151283F(1)-2015-3D

$\begin{array}{lcccccccccccccccc}\text { ID } & 79 & 78 & 78 & 78 & 78 & 78 & 98 & 98 & 97 & 97 & 98 & 97 & 98 & 92 & 98 & 98 \\ \mathbf{9 1} & \text { I } & 100 & 96 & 100 & 96 & 96 & 79 & 79 & 79 & 79 & 79 & 79 & 79 & 80 & 79 & 79 \\ \mathbf{9 0} & \mathbf{9 9} & \text { ID } & 96 & 100 & 96 & 96 & 79 & 79 & 79 & 79 & 79 & 79 & 78 & 80 & 79 & 79 \\ \mathbf{9 1} & \mathbf{1 0 0} & \mathbf{9 9} & \text { ID } & 96 & 100 & 100 & 80 & 79 & 79 & 80 & 80 & 80 & 79 & 82 & 80 & 79 \\ \mathbf{9 0} & \mathbf{9 9} & \mathbf{1 0 0} & \mathbf{9 9} & \text { ID } & 96 & 96 & 79 & 79 & 79 & 79 & 79 & 79 & 78 & 80 & 79 & 79 \\ & & & & & & & & & & & & & & & & \\ \mathbf{9 1} & \mathbf{1 0 0} & \mathbf{9 9} & \mathbf{1 0 0} & \mathbf{9 9} & \text { ID } & 100 & 80 & 79 & 79 & 80 & 80 & 80 & 79 & 82 & 80 & 79 \\ \mathbf{9 1} & \mathbf{1 0 0} & \mathbf{9 9} & \mathbf{1 0 0} & \mathbf{9 9} & \mathbf{1 0 0} & \text { ID } & 80 & 79 & 79 & 80 & 80 & 80 & 79 & 82 & 80 & 79 \\ \mathbf{9 8} & \mathbf{9 2} & \mathbf{9 1} & \mathbf{9 2} & \mathbf{9 1} & \mathbf{9 2} & \mathbf{9 2} & \text { ID } & 100 & 99 & 100 & 99 & 99 & 99 & 94 & 100 & 100 \\ \mathbf{9 8} & \mathbf{9 2} & \mathbf{9 1} & \mathbf{9 2} & \mathbf{9 1} & \mathbf{9 2} & \mathbf{9 2} & \mathbf{1 0 0} & \text { ID } & 99 & 99 & 99 & 99 & 99 & 93 & 100 & 100 \\ \mathbf{9 9} & \mathbf{9 1} & \mathbf{9 1} & \mathbf{9 1} & \mathbf{9 1} & \mathbf{9 1} & \mathbf{9 1} & \mathbf{9 9} & \mathbf{9 9} & \text { ID } & 98 & 99 & 98 & 99 & 93 & 99 & 99 \\ \mathbf{9 8} & \mathbf{9 2} & \mathbf{9 1} & \mathbf{9 2} & \mathbf{9 1} & \mathbf{9 2} & \mathbf{9 2} & \mathbf{1 0 0} & \mathbf{1 0 0} & \mathbf{9 9} & \text { ID } & 99 & 99 & 99 & 94 & 100 & 99 \\ \mathbf{9 9} & \mathbf{9 1} & \mathbf{9 1} & \mathbf{9 1} & \mathbf{9 1} & \mathbf{9 1} & \mathbf{9 1} & \mathbf{9 9} & \mathbf{9 9} & \mathbf{1 0 0} & \mathbf{9 9} & \text { ID } & 99 & 99 & 93 & 99 & 99 \\ \mathbf{9 8} & \mathbf{9 3} & \mathbf{9 2} & \mathbf{9 3} & \mathbf{9 2} & \mathbf{9 3} & \mathbf{9 3} & \mathbf{9 9} & \mathbf{9 9} & \mathbf{9 8} & \mathbf{9 9} & \mathbf{9 8} & \text { ID } & 99 & 93 & 99 & 99 \\ \mathbf{9 9} & \mathbf{9 1} & \mathbf{9 1} & \mathbf{9 1} & \mathbf{9 1} & \mathbf{9 1} & \mathbf{9 1} & \mathbf{9 9} & \mathbf{9 9} & \mathbf{1 0 0} & \mathbf{9 9} & \mathbf{1 0 0} & \mathbf{9 8} & \text { ID } & 93 & 99 & 99 \\ \mathbf{9 6} & \mathbf{9 3} & \mathbf{9 2} & \mathbf{9 3} & \mathbf{9 2} & \mathbf{9 3} & \mathbf{9 3} & \mathbf{9 6} & \mathbf{9 6} & \mathbf{9 7} & \mathbf{9 6} & \mathbf{9 7} & \mathbf{9 6} & \mathbf{9 7} & \text { ID } & 94 & 93 \\ \mathbf{9 8} & \mathbf{9 2} & \mathbf{9 1} & \mathbf{9 2} & \mathbf{9 1} & \mathbf{9 2} & \mathbf{9 2} & \mathbf{1 0 0} & \mathbf{1 0 0} & \mathbf{9 9} & \mathbf{1 0 0} & \mathbf{9 9} & \mathbf{9 9} & \mathbf{9 9} & \mathbf{9 6} & \text { ID } & 100 \\ \mathbf{9 8} & \mathbf{9 2} & \mathbf{9 1} & \mathbf{9 2} & \mathbf{9 1} & \mathbf{9 2} & \mathbf{9 2} & \mathbf{1 0 0} & \mathbf{1 0 0} & \mathbf{9 9} & \mathbf{1 0 0} & \mathbf{9 9} & \mathbf{9 9} & \mathbf{9 9} & \mathbf{9 6} & \mathbf{1 0 0} & \text { ID }\end{array}$

Figure 3. Deduced amino acid sequence of the 3D gene of the isolated strains in comparison to published vaccinal, reference and field Egyptian strains.

200 


\section{Ali Zanaty et al (2017)}

Majority

DHV/Duck/Egypt/Al-Gharbia/2014

Duck hepatitis A virus 1 strain E53

DHV A strain vaccine polyprotein gene

Duck hepatitis A virus strain F387

Duck hepatitis A virus strain Egypt/vac

Duck hepatitis A strain F10

Duck hepatitis A virus strain F 413

DHV-EGYPT / $14921 \mathrm{~F}-2014-3 \mathrm{D}$

DHV-EGYPT/14923F-2014-3D

DHV-EGYPT/141122F-2014-3D

DHV-EGYPT/151283F (3)-2015-3D

DHV-EGYPT / 15298F-2015-3D

DHV-EGYPT / 15P18-2015-3D

DHV-EGYPT/151283F ( 4)-2015-3D

DHV-EGYPT/ 16160F-2016-3D

DHV-EGYPT/151283F (2)-2015-3D

DHV-EGYPT / 151283F (1)-2015-3D

DHV/Duck/Egypt/Al-Gharbia/2014

Duck hepatitis A virus 1 strain E53

DHV A strain vaccine polyprotein gene

Duck hepatitis A virus strain F387

Duck hepatitis A virus strain Egypt/vac

Duck hepatitis A strain F10

Duck hepatitis A virus strain F 413

DHV-EGYPT / 14921F-2014-3D

DHV-EGYPT/14923F-2014-3D

DHV-EGYPT/141122F-2014-3D

DHV-EGYPT/151283F (3)-2015-3D

DHV-EGYPT/15298F-2015-3D

DHV-EGYPT / 15P18-2015-3D

DHV-EGYPT/151283F (4)-2015-3D

DHV-EGYPT/16160F-2016-3D

DHV-EGYPT/151283F (2)-2015-3D

DHV-EGYPT / 151283F (1) -2015-3D
RGIEACNFDYTVAYRMVMGEIYSNIYDDSFILSGCAVGINPFAEWDNLLANLQPYNLCLDFSGFDGSLSAQILEEAVDVI

$$
10
$$

20

30

40

50

60

70

80

RGIEACNFDYTVAFRMVMGEIYSNIYDDSFILSGCAVGINPFAEWDNLLANLQPYNLCLDFSGFDGSLSAOILEFAVDVI

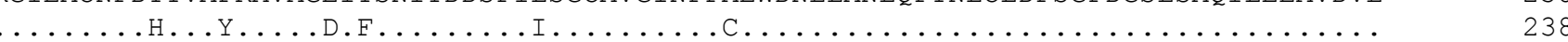

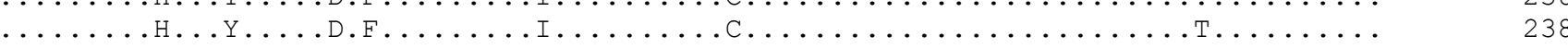

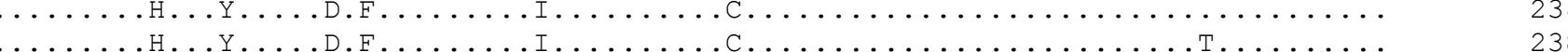

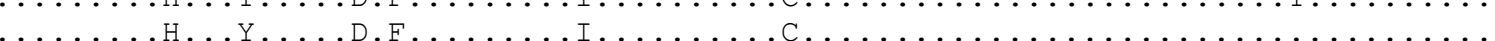

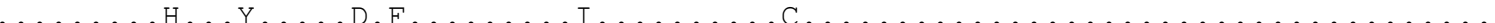

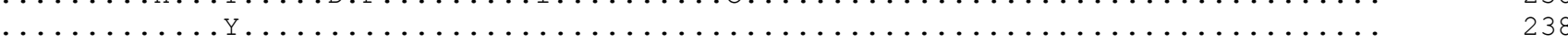

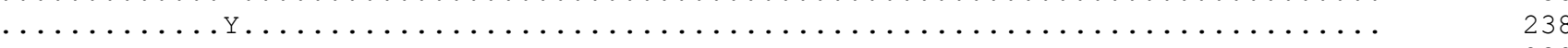

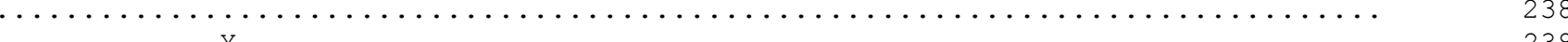

...

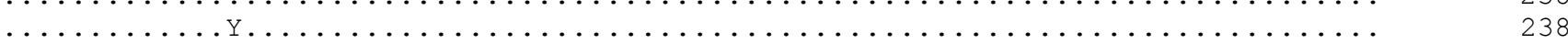

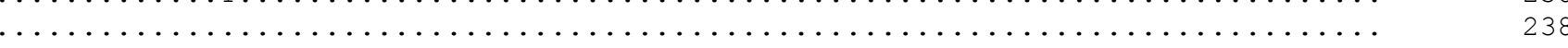

$\ldots \ldots \ldots \ldots+\ldots$

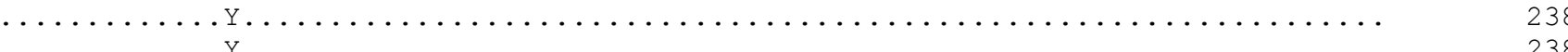

SFFHNDATVKKIHEPTIYSTHYVTDETWKVEGGMCSGSPCTTVINSI

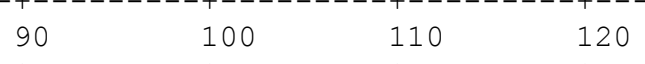

SFFHNDPALVKKIHEPTIYSTHYVTDE IWKVEGGMCSGSPCTTVLNSN

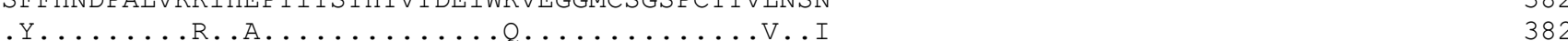

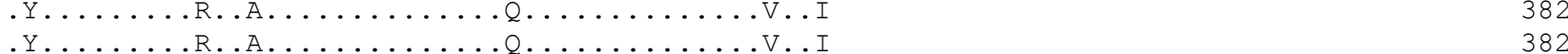

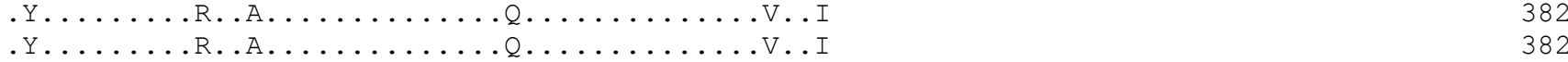

.Y.....R..A.................I

.Y.....R.A.................I

.Y.....R..A.................I

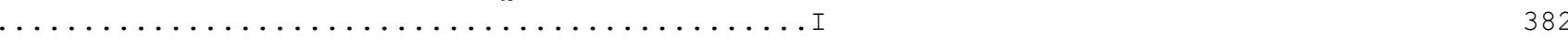

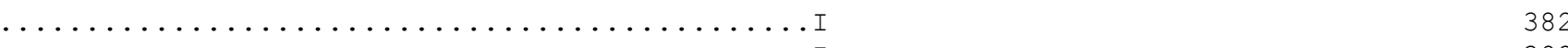

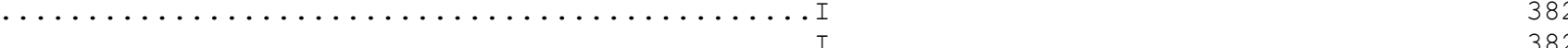

(1)

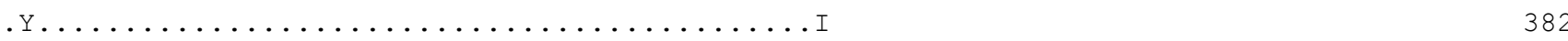

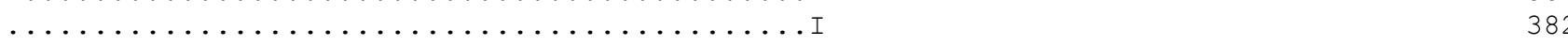

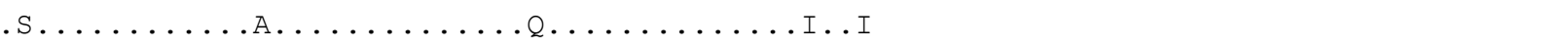

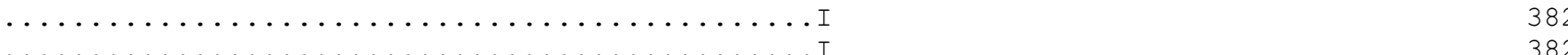

201 
Dots indicate identical residues.

\section{Discussion}

In Egypt, the actual cause of DHAV infection in vaccinated ducks flocks is not well known. It may be due to antigenic differences in field virus; hence the used vaccine cannot induce a good protection or due to low maternal derived antibody titer. Nucleotide identity 3D of the Egyptian strains with the local strain of DHAV (vaccine strain) was 95-95.9\% and 98\% identity to the closest Asian strains (Erfan et al., 2015). The highly conserved GxxCSGxxTxxNS motif in the $3 \mathrm{D}$ of all picornaviruses was detected in the Egyptian strains like other DHAVs (Wang et al., 2008). Detection of DHAV is confirmed by high mortality and rapid onset of clinical symptoms in ducklings, inoculation of tissues homogenate into allantoic sacs of embryonated duck eggs (EDEs) and embryonated chicken eggs (ECEs) or infection of cell culture (OIE, 2010). In contrast to the difficult and time- consuming viral isolation and serological tests (Woolcock et al., 1982; Zhao et al., 1991), rapid and specific diagnosis of the DHAV RNA using different RT-PCR techniques were developed (Kim et al., 2007; Liu et al., 2007; Anchun et al., 2009, OIE, 2010).

In this work, 20 DHAV samples from commercial duck flocks from 9 governorates were analysed by RT-PCR of 450bp of the 3D gene for DHAV. Ten samples out of 20 total samples were found positive for DHAV (50\%), displaying a serious health problem for the duck manufacturing in Egypt. Consequently, nationwide surveillance is recommended. To date, resistance of certain breeds of ducks to DHAV is not well known (Woolcock, 2003). As obtained here, the virus was isolated from Pekin, Muscovy and Mallards ducks. Since no report existed regarding the vaccination status of the flocks so it is not clear whether the disease signs occur due to strain variation or lack of vaccination. In China several vaccines were updated according to the circulating viruses in the field, nevertheless the infection of vaccinated ducklings was reported (Jin et al., 2008; Li et al., 2013). The lack of the lesions in EDE and the existence of mutations previously reported in attenuated tissue-adapted strains (Wang et al., 2012) might indicate that the Egyptian strains differ in their virulence to the
Asian viruses; therefore in vivo pathogenicity testing is highly required.

Microscopic examination of livers of collected samples showed pronounced hyperaemic blood vessels, dilated sinusoids with haemolysed RBCs, vacuolar degeneration, hepatocellular necrosis, perivascular invasion with granulocytes and perivascular amyloidosis (Figure 1). These results were parallel to those documented by Fitzgerald et al. (1996) and Sheng et al. (2014).

The 3D and 2C proteins of DHAV are two of the most conserved proteins among the end products of the family Picornaviridae, probably due to functional constraints (Gromeier et al., 1999). Accordingly, the amino acid sequences of the $3 \mathrm{D}$ and $2 \mathrm{C}$ proteins of members of the family Picornaviridae are commonly used for inferring phylogenetic relationships between viruses belonging to different genera within the family (Domingo et al., 1995; Po“yry et al., 1996; Gromeier et al., 1999).

Sequencing of amplified region for further genotyping was done. The molecular data indicated that the DHAV isolated in Egypt during the last three years were similar to those isolated from the Asian countries. Although the number of gene sequences of DHAV is substantially increasing providing useful information on the taxonomy, epidemiology and virulence of the virus, however it is limited to few countries only (Kim et al., 2006; Ding and Zhang, 2007; Tseng et al., 2007; Tseng and Tsai, 2007).The phylogenetic tree presented here showed that the Egyptian strains are distinguishable from the vaccine strain where the identity was 78 to $80 \%$ (Nucleotide) and 91 to $92 \%$ (Amino acids) according to the 3D genes (Table 2, Figure 1).

In conclusion, DHAV-1 was detected in 10 out of 20 commercial duck farms of different breeds examined in this study. Sequence and phylogenetic analyses indicated that the Egyptian strains are distinguishable from the vaccine and similar to the contemporary Asian viruses. 


\section{References}

Abd-Elhakim, MA, Thieme O, Schwabenbauer K, Ahmed ZA, (2009). Mapping traditional poultry hatcheries in Egypt. In: AHBL Promoting Strategies for Prevention and Control of HPAI, FAO, ed.Food and Agriculture Organisation of the United Nations (FAO), Rome, Italy.

Anchun CW. Mingshu X. Hongyi Z. Dekang L. Xinran C. Haijuen J. Renyong and Miao Y. (2009). Development and application of a reverse transcriptase polymerase chain reaction to detect Chinese isolates of duck, hepatitis virus type 1. J. Microbiol. Methods, 76(1): 1-5.

Babcroft, JD and Gamble M. (2008).Theory and practice of histological techniques (Elsevier health sciences).

Bayoumie HAA. and Abd EL-Samie LK. (2015). Molecular characterization of a duck virus hepatitis isolated from Sharkia governorate. Assiut Vet. Med. J., 61(147): 5665.

Ding C. and Zhang D, (2007). Molecular analysis of duck hepatitis virus type 1 . Virology, 361: 9-17.

Domingo E, Mateu M G. Escarmis C., Martinez-Salas

E., Andreu D. Giralt E. Verdaguer N. \& Fita I. (1995).

Molecular evolution of aphthoviruses. Virus Genes 11, 197-207.

Ellakany H, El Sebai AH, Sultan H. Sami AA. (2002). Control of experimental DHV infection by amantadine. In: Proceedings of the 6thScientific Veterinary Medical Conference of Zagazig University, Zagazig University, Hurghada, Egypt, pp. 757-775.

Erfan AM. Selim, AA. Moursi, MK. Nasef SA and Abdelwhab EM. (2015). Epidemiology and molecular characterisation of duck hepatitis A virus from different duck breeds in Egypt. Vet Microbiol. 177(3-4): 347-352.

Fitzgerald JE. Hanson LE. and Simon J.(1996). Histopathologic changes induced with duck hepatitis virus in the developing chicken embryo. Avian Dis., 13: 147-157.

$\mathrm{Fu}$ Y. Pan M, Wang X. Xu Y, Yang H. and. Zhang D (2008). Molecular detection and typing of duck hepatitis A virus directly from clinical specimens. Vet. Microbiol, 131: 247257.

Gabridge MG. and Newman JP. (1971). Gel diffusion method for determining the titer of duck hepatitis virus. Appl. Microbiol, 21: 147-148. 177(3-4): 347-352.

Gromeier M. Wimmer E. \& Gorbalenya AE. (1999). Genetics, pathogenesis and evolution of picornaviruses. In Origin and Evolution of Viruses, pp. 287-343. Edited by E. Domingo, R. Webster \& J. Holland. San Diego: Academic Press.

Guerin JL. Albaric O. Noutary V. and Boissieu C. (2007). A duck hepatitis virus type I is agent of pancreatitis and encephalitis in Muscovy duckling. In: Proceedings of the 147th American Veterinary Medicine Association $150^{\text {th }}$ American Association of Avian Pathologists Conference, Washington, DC, USA, Abs 4585, 14-18 July 2007.

Hall T. (1999). BioEdit: a user-friendly biological sequence alignment editor and analysis program for Windows 95/98/NT. Nucleic Acids Symp. Ser. 41, 95-98.

Hwang J. (1969). Duck hepatitis virusneutralization test in chicken embryos. Am. J. Vet. Res., 30: 861-864

Jin X. W. Zhang WP. Zhang CQ. Gu GF and. $\mathrm{Hu}$ XY (2008). Identification and molecular analysis of the highly pathogenic duck hepatitis virus type 1 in Hubei province of China. Res. Vet. Sci., 85: 595-598.

Kerkvliet J. Edukulla R. and Rodriguez M. (2010). Adv. Virol. Vol.2010doi: 10.1155/2010/ 368068.

Kim MC. YK. Kwon SJ. Joh, AM. Lindberg JH. Kwon JH. Kim and Kim SJ. (2006). Molecular analysis of duck hepatitis virus type 1 reveals a novel lineage close to the genus Parechovirus in the family Picornaviridae. J. Gen. Virol., 87: 3307-3316. Kim MC. Kwon YK. Joh SJ, Kim SJ. Tolf C. Kim JH. Sung HW Lindberg A. and Kwon JH. (2007). Recent Korean isolates of duck hepatitis virus reveal the presence of a new geno-and serotype when compared to duck hepatitis virus type 1 type strains. Arch. Virol., 152: 2059-2072.

Knowles NJ. Hovi T. Hyypiä T. King AMQ. Lindberg AM. Pallansch MA. Palmenberg AC. Simmonds P. Skern T. Stanway G.Yamashita T. and Zell R. (2012). Picornaviridae. In: King, A.M.Q., M.J. Adams, E.B. Carstens, E.J. Lefkowitz, eds. Virus Taxonomy: Classification and Nomenclature of Viruses: Ninth Report of the International Committee on Taxonomy of Viruses. Elsevier, San Diego, pp: 855-880. 
Levine PP. and Fabricant J. (1950). A hithertoundescribed virus disease of ducks in North America. Cornell Vet., 40: 71-86.

Li J. Bi Y. Chen C. Yang, L. Ding C. Liu W. (2013). Genetic characterization of duck hepatitis A viruses isolated in China. Virus Res. 178, 211-216.

Ling KS. WP. Wechter and Jordan R. (2007). Development of a one-step immunocapture real-time TaqMan RT-PCR assay for the broad spectrum detection of Pepino mosaic virus. J. Virol. Methods, 144: 65-72.

Liu GQ. Wang F. Z. Ni T. Yun and Yu B. (2007). Complete genomic sequence of a Chinese isolate of duck hepatitis virus. Virol. Sin., 22: 353-359.

Mahdy SA. (2005). Clinicopathological studies onthe effect of duck viral hepatitis in ducks. M.V.Sc Thesis (Clinical Pathology), Faculty of Veterinary Medicine, Zagazig University.

OIE (2010). Duck Virus Hepatitis. OIE Terrestrial Manual 2010. (Chapter 2.3.8), available online at: http:// www.oie.in t/fileadmin/ Home/ eng/ Health_standards/tahm/2.03.08_DVH.pdf.

Po" yry T. Kinnunen L. Hyypia T. Brown B. Horsnell C. Hovi T. \& Stanway G. (1996). Genetic and phylogenetic clustering of enteroviruses . J Gen Virol 77, 1699-1717.

Saif YM. Barnes H J. Glissons JR. Fadly AM. McDougald LR and Swayne DE. (2003). Diseases of Poultry, Iowa State Press, Ames, Iowa, USA, 11th edition,

Shalaby MA. Ayoub MNK and Reda IM. (1972). A study on a new isolate of duck hepatitis virus and its relationship to other duck hepatitis virus strains. Vet. Med. J. Cairo Univ, 26: 215-221.

Sheng XD, Zhang WP. Zhang QR. Gu CQ. and $\mathrm{Hu}$ XY. and Cheng GF. (2014). Apoptosis induction in duck tissues during duck hepatitis A virus type 1 infection. Poultry Sci., 93: 527534.

Tamura K. Stecher G. Peterson D. Filipski A. and Kumar S. (2013): MEGA6: molecular evolutionary genetics analysis version 6.0. Mol. Biol. Evol. 30, 2725-2729.

Taylor PL. and Hanson LE. (1967). Indirect hemagglutination with duck hepatitis virus. Avian Dis., 11: 586-593.

Tseng CH. Knowles NJ. and Tsai HJ. (2007). Molecular analysis of duck hepatitis virus type 1indicates that it should be assigned to a new

Virus Res., 123: 190-203.
Tseng CH. Tsai HJ. (2007). Molecular characterization of a new serotype of duck hepatitis virus. Virus Res. 126, 19-31.

Vertinskii K. Bessarabov B. Kurilenko A. Strel'nikov A. and Makhno P. (1986). The pathogenesis and diagnosis of viral hepatitis of ducklings. Veterinariia, , 45: 27-30. (In Russian)

Wang LM. Pan Y. Zhang D. (2008). Classification of duck hepatitis virus into three genotypes based on molecular evolutionary analysis.Virus Genes. 37: 52-59.

Wang Y, Li C, Chen Z. Xu B, Li G, Liu G, (2012). Complete genome comparison of duck hepatitis virus type 1 parental and attenuated strains. Virus Genes 45, 398-401.

Woolcock PR, (2003). Duck hepatitis. In: Saif Y.M., H.J. Barnes, J.R. Glisson AM. Fadly L.R. Mcdougald and D.E. Swayne, eds. Diseases of Poultry. Eleventh ed. Iowa State Press, Ames, IA., pp: 343-354.

Woolcock PR. Chalmers WSK and Davis D. (1982). A plaque assay for duck hepatitis virus. Avian Path.11 (4): 607-610.

Zhao X, Phillips RM, Li G. and Zhong A, (1991). Studies on the detection of antibody to duck hepatitis virus by enzyme-linked immunosorbent assay. Avian Dis., 35 
Ali Zanaty et al (2017) 